\title{
Primary varicella zoster infection with tongue lesions
}

\author{
Alexander Moylan, ${ }^{1}$ Emma Karsten, ${ }^{1}$ Shunmay Yeung, ${ }^{2}$ Francesca Cleugh ${ }^{1}$
}

${ }^{1}$ Paediatric Emergency Medicine, Imperial College Healthcare NHS Trust, London, UK ${ }^{2}$ Department of Global Health, LSHTM, London, UK

\section{Correspondence to}

Dr Alexander Moylan, alexander.moylan@nhs.net

Accepted 20 October 2018

\section{DESCRIPTION}

A 4-year-old girl presented to the paediatric emergency department with a 5-day history of a widespread vesicular rash associated with evolving tongue lesions (figure 1).

On examination, she was systemically well with no fevers. She had extensive white dome-shaped papules on both sides of her tongue. These had reportedly appeared from the second day of her illness as pruritic vesicles which she had chewed on. She described her tongue as sore and had only been managing to drink small amounts. She had a generalised skin rash typical of primary varicella zoster infection with new crops of vesicles continuing to appear.

She had a history of anaphylaxis to nuts and mild eczema that was well controlled but was not on any immunosuppressive therapy and did not have a history suggestive of a primary or secondary immunodeficiency. She had been immunised according to the UK schedule.

We diagnosed her tongue lesions as primary varicella zoster infection. Although of uncertain benefit given the duration of her illness, after discussion with her mother, we discharged her with a course of oral acyclovir and benzydamine spray

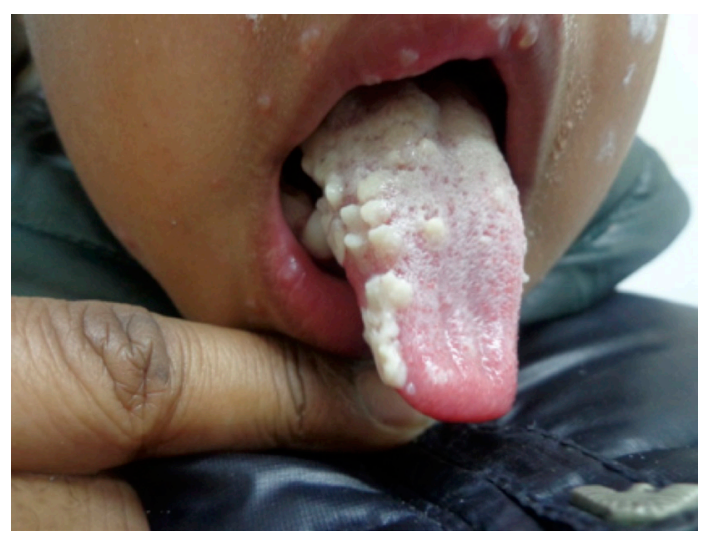

Figure 1 Appearance of tongue on day 5 of illness.

\section{Patient's perspective}

Comment from the child's mother:

I would just like to add that the doctors said that medication would not significantly benefit my daughter. However, I was adamant that I would like to try medication to help my daughter even if it was a little. The medication greatly improved the itching and my daughter tongue after 24 hours looked better and she was less irritated.

I strongly recommend that if a child comes to A\&E to be given medication as it will definitely make the child more comfortable and get better sooner!

\section{Learning points}

- Papillary tongue lesions can occur in primary varicella zoster infection and benzydamine spray can be used for symptomatic relief.

for symptomatic benefit. A swab of her tongue confirmed the presence of varicella zoster by PCR and was negative for herpes simplex virus.

A search of PubMed using the terms ((lingual or tongue) AND varicella) found no previous reports of primary varicella lesions on the tongue. In this case, she found significant benefit from benzydamine spray and her symptoms resolved over the following 3 days.

Contributors All authors were involved in the treatment of the child. The report was drafted by EK and AM and thoroughly reviewed and amended by FC and SY.

Funding The authors have not declared a specific grant for this research from any funding agency in the public, commercial or not-for-profit sectors.

Competing interests None declared.

Patient consent Parental/guardian consent obtained.

Provenance and peer review Not commissioned; externally peer reviewed. 
Copyright 2018 BMJ Publishing Group. All rights reserved. For permission to reuse any of this content visit http://group.bmj.com/group/rights-licensing/permissions.

BMJ Case Report Fellows may re-use this article for personal use and teaching without any further permission.

Become a Fellow of BMJ Case Reports today and you can:

- Submit as many cases as you like

- Enjoy fast sympathetic peer review and rapid publication of accepted articles

Access all the published articles

- Re-use any of the published material for personal use and teaching without further permission

For information on Institutional Fellowships contact consortiasales@bmjgroup.com

Visit casereports.bmj.com for more articles like this and to become a Fellow 